\title{
BAFF is involved in the pathogenesis of IgA nephropathy by activating the TRAF6/NF-кB signaling pathway in glomerular mesangial cells
}

\author{
YINGJIE CAO ${ }^{1,2}$, GUOYUAN LU $^{1}, \mathrm{XIAOLAN} \mathrm{CHEN}^{2}, \mathrm{XU} \mathrm{CHEN}^{2}, \mathrm{NAIFENG} \mathrm{GUO}^{2}$ and WENWEN $\mathrm{LI}^{2}$ \\ ${ }^{1}$ Department of Nephrology, The First Affiliated Hospital of Soochow University, Suzhou, Jiangsu 215006; \\ ${ }^{2}$ Department of Nephrology, The Affiliated Hospital of Nantong University, Nantong, Jiangsu 226000, P.R. China
}

Received March 5, 2019; Accepted October 30, 2019

DOI: $10.3892 / \mathrm{mmr} .2019 .10870$

\begin{abstract}
The aim of the present study was to investigate the involvement of B cell-activating factor (BAFF) in the pathogenesis of $\operatorname{IgA}$ nephropathy by activating the tumor necrosis factor receptor-associated factor 6 (TRAF6)/NF- $\mathrm{BB}$ signaling pathway in glomerular mesangial cells. For the clinical analysis, blood, urine and kidney tissue samples were collected from 58 patients diagnosed with primary $\operatorname{IgA}$ nephropathy by renal biopsy. For the in vitro study, glomerular mesangial cells were divided into five groups: Control (con)-short hairpin RNA (shRNA) (control group); con-shRNA + BAFF $(20 \mathrm{ng} / \mathrm{ml})$; con-shRNA + BAFF + BAFF-RFc chimera protein (500 $\mu \mathrm{g} / \mathrm{ml})$; TRAF6-shRNA; and TRAF6-shRNA + BAFF (20 ng/ml). For the in vivo experiments, 60 Sprague-Dawley rats were randomly divided into four groups: Con-small interfering RNA (siRNA) (control group); con-siRNA + IgA (IgA nephropathy group), BAFF-RFc chimera protein $(2 \mu \mathrm{g} / \mathrm{ml})+\operatorname{IgA}$, and TRAF6-siRNA $(0.2 \mu \mathrm{M})+\operatorname{IgA}$. Reverse transcription-quantitative PCR was performed to evaluate the mRNA expression levels of TRAF6, connective tissue growth factor (CTGF), fibronectin (FN) and NF- $\kappa$ BP65. Western blot analysis was used to detect the protein expression levels of TRAF6, FN, CTGF and phosphorylated-NF-кBP65 in glomerular mesangial cells and kidney tissues. The results revealed that plasma BAFF levels were positively correlated with the severity of pathological damage in patients with IgA nephropathy. In vitro, BAFF induced the mRNA and protein expression of TRAF6, CTGF, FN and NF- $\kappa$ BP65 in glomerular mesangial cells. After the BAFF-RFc chimera protein
\end{abstract}

Correspondence to: Dr Guoyuan Lu, Department of Nephrology, The First Affiliated Hospital of Soochow University, 188 Shizi Street, Suzhou, Jiangsu 215006, P.R. China

Email: luguoyuan@medmail.com.cn

Abbreviations: BAFF, B cell-activating factor; TNF, tumor necrosis factor; TRAF, TNF receptor-associated factor

Key words: BAFF, IgA nephropathy, TRAF6, NF-кB, mesangial cells was added to inhibit the binding of BAFF and BAFF-receptor $(-\mathrm{R})$, this effect was reduced. In vivo, inhibition of the effects of BAFF via injection with the BAFF-R Fc chimera protein reduced kidney damage in rats suffering from $\operatorname{IgA}$ nephropathy. The effect on the expression of signaling pathway-associated proteins was also alleviated. In conclusion, BAFF enhanced the expression of fibroblast factors in the kidneys by activating the TRAF6/NF- $\kappa \mathrm{B}$ signaling pathway.

\section{Introduction}

IgA nephropathy is the most important factor that leads to end-stage kidney disease progression (1). It is well known that IgA nephropathy is a progressive disease. The diagnosis of IgA nephropathy depends on the pathological diagnosis of renal biopsy; the most prominent characteristic of $\operatorname{IgA}$ nephropathy is IgA1-based immune complexes deposited in the glomerular mesangial region (2), which induce the proliferation and secretion of glomerular mesangial cells. Inflammatory factors and chemokines then mediate glomerular inflammatory damage $(3,4)$. Since the pathogenesis is currently unclear, there is no specific treatment for IgA nephropathy. In addition, as $\operatorname{Ig} \mathrm{A}$ nephropathy is a progressive disease, its progressive mechanism should be studied, and interventional measures that delay or reverse the progress of $\operatorname{Ig} \mathrm{A}$ nephropathy should be identified.

Previous studies have reported that IgA1 is mainly derived from activated B lymphocytes. B cell-activating factor (BAFF) is a novel member of the tumor necrosis factor (TNF) superfamily (5-8). It has been reported that BAFF, as an important co-stimulatory factor, is critical in mediating B-cell proliferation, maturation and antibody secretion. Numerous studies have suggested that BAFF may be involved in the pathogenesis of IgA nephropathy (9-14). TNF receptor-associated factor (TRAF) is an important linker molecule in the TNF superfamily; TRAF6 is involved in inflammation and immune responses by mediating inflammatory and apoptotic signaling pathways (15). In addition, TRAF may serve a key role by activating the $\mathrm{NF}-\kappa \mathrm{B}$ signaling pathway (16-23). A previous study reported that BAFF activates $B$ cells through the $N F-\kappa B$ signaling pathway to secrete excess $\operatorname{Ig} \mathrm{A} 1$, which leads to $\operatorname{Ig} \mathrm{A}$ nephropathy-like alterations in mouse kidneys (14). Previous 
studies indicated that B-cell activation and elevated BAFF levels were present in patients with IgA nephropathy $(10,11)$. In addition, it was suggested that overexpression of BAFF may be involved in the pathogenesis of IgA nephropathy by inducing white blood cells to secrete abnormal glycosylated IgA1 (14). However, it is unclear whether overexpression of BAFF results in damage to the renal parenchyma.

In the present study, primary glomerular mesangial cells were cultured and BAFF was added to detect possible signaling pathways. Rat models of IgA nephropathy were also generated to examine the effect of BAFF on TRAF6/NF- $\mathrm{KB}$ signaling pathways. Briefly, the aim of the present study was to investigate whether BAFF directly damaged the renal parenchyma. These studies may help to further explore the pathogenesis of IgA nephropathy and may aid development of targeted therapeutic strategies.

\section{Materials and methods}

Study cases. The present study recruited 58 patients diagnosed with primary IgA nephropathy by renal biopsy between February 2016 and December 2017 from The Affiliated Hospital of Nantong University (Nantong, China). The recruited patients included 23 women and 35 men, with an average age of $39.21 \pm 9.3$ years. In addition, 20 patients with renal necrosis caused by renal tumors were recruited as the control group from the Department of Urology, The Affiliated Hospital of Nantong University between February 2016 and December 2017. The patients in the control group comprised 12 women and 8 men, with an average age of $49.32 \pm 11.27$ years. The study protocol was approved by the medical ethics committee of The Affiliated Hospital of Nantong University, and all subjects provided written informed consent.

This study excluded patients with secondary kidney disease, such as systemic lupus erythematosus, Henoch-Schonlein purpura, ankylosing spondylitis, liver disease and tumors. Patients were not systematically treated and did not use immunosuppressive agents prior to the start of the study.

A total of $8 \mathrm{ml}$ anticoagulated blood was collected from the upper arms of patients that were fasted for 1 night. Each collected sample was centrifuged at 1,200 $\mathrm{x}$ g for $10 \mathrm{~min}$ at room temperature, and the plasma was collected and maintained in an Eppendorf tube at $-80^{\circ} \mathrm{C}$ for storage. For examination, the frozen plasma was rapidly thawed at $37^{\circ} \mathrm{C}$. Urine was collected at 8:00 $\mathrm{AM}$ and urine samples were subsequently taken for $24 \mathrm{~h}$; toluene $(4-5 \mathrm{ml})$ was added to prevent corrosion. The kidney tissue specimens of patients with IgA nephropathy were obtained by ultrasound-guided percutaneous nephrolithotomy. The kidney tissue specimens of patients with renal tumors were collected from normal kidney tissues away from the tumor site following removal of the kidney. The obtained kidney tissues were partially fixed for $2 \mathrm{~h}$ at room temperature in $10 \%$ formalin solution post-surgery, and partial kidney tissues were placed in liquid nitrogen and stored at $-80^{\circ} \mathrm{C}$.

Detection of urinary protein quantity and endogenous creatinine clearance rate. The protein in urine was added to $1.5 \%$ sodium tungstate and centrifuged at $3,000 \mathrm{x}$ g for $5 \mathrm{~min}$ at room temperature, and was then quantitatively determined by the biuret method (24). The concentration of creatinine in urine and plasma was measured using the Modular P800 Automatic Biochemistry Analyzer (Roche Diagnostics), and urine volume was measured for $24 \mathrm{~h}$. The Cockcroft formula (25) was used to calculate the clearance rate of endogenous creatinine for $24 \mathrm{~h}$.

Detection of plasma BAFF. An ELISA kit (cat. no. ab188391; Abcam) was used to detect BAFF levels in plasma samples, according to the manufacturer's protocol. The absorbance was measured at $450 \mathrm{~nm}$, according to the manufacturer's protocol. A standard curve was generated according to the dilution concentration, in order to calculate the concentration of BAFF in each specimen.

Immunohistochemical analysis of kidney tissues. The obtained kidney tissues were fixed for $2 \mathrm{~h}$ at room temperature with $4 \%$ formalin, dehydrated in an ascending series of ethanol, and permeabilized by xylene. Sections were then immersed in wax, embedded in paraffin, sliced into $2-\mu \mathrm{m}$ sections, dried, dewaxed and subjected to antigen retrieval with $0.01 \mathrm{M}$ citrate buffer for $40 \mathrm{~min}$ at $92^{\circ} \mathrm{C}$. The slides were then incubated with $3 \% \mathrm{H}_{2} \mathrm{O}_{2}$ for $10 \mathrm{~min}$ at room temperature to quench endogenous peroxidase activity, placed in $0.01 \mathrm{mmol} / \mathrm{l}$ citrate buffer $(\mathrm{pH}$ 6.0) and rinsed three times with $0.01 \mathrm{~mol} / \mathrm{l} \mathrm{PBS}$ for $3 \mathrm{~min}$. Anti-human BAFF antibody (1:50; cat. no. AF124; R\&D Systems, Inc.), anti-p-NF-кBP65 (1:1,000; cat. no. ab86299; Abcam) or rabbit anti-TRAF6 antibody (1:100; cat. no. sc-8409; Santa Cruz Biotechnology, Inc.) were used to incubate slides overnight at $4^{\circ} \mathrm{C}$. PBS was used to rinse slides following primary antibody incubation. Horseradish peroxidase (HRP)-labeled secondary antibody (1:500; cat. nos. A0181 and A0208; Beyotime Institute of Biotechnology) was then added for $30 \mathrm{~min}$ at room temperature, followed by washing with PBS. PBS was used instead of primary antibodies as a negative control. 3,3'-Diaminobenzidine was used to stain the slides for $20 \mathrm{~min}$, and hematoxylin was used for counterstaining for $1 \mathrm{~min}$ at room temperature. The slides were then dehydrated and mounted. Light microscopy was employed for observations and image capturing. Brown-yellow particles were regarded as positive cells and six fields were randomly selected from each slice. The integrated optical density values were determined using Image-ProPlus 6.0 image analysis processing software (Media Cybernetics, Inc.), and the average value was used to determine the expression level.

Histopathological scores of kidney tissues. According to the Katafuchi score (26) of IgA nephropathy, the score of glomerular lesions was classified as $0-12$ points, including: i) The degree of glomerular mesangial cell and mesangial matrix hyperplasia (0-4 points); ii) segmental glomerular lesions, such as crescent formation, glomerular adhesion, segmental sclerosis and segmental capillary fibrinous necrosis (0-4 points); and iii) glomerular sclerosis ( $0-4$ points). The integral evaluation criteria were: 1 , none, 0 points; $2,<25 \%, 1$ point; 3 , 25-50\%, 2 points; 4, 51-75\%, 3 points; and 5, >75\%, 4 points. A total of 58 patients with IgA nephropathy were divided into four groups according to the scores: $0-3$ points (group I), 4-6 points (group II), 7-9 points (group III), and 10-12 points (group IV). 
Glomerular mesangial cell culture. The animal protocol in the present study was approved by the Medical Ethics Committee of The Nantong University Affiliated Hospital. Two male Sprague-Dawley rats (age, 8 weeks; weight, 220-260 g), supplied by the laboratory animal center of Nantong University, were housed under the following conditions: Temperature, $18-26^{\circ} \mathrm{C}$; relative humidity, $40-70 \%$; noise, $<85 \mathrm{~dB}$; ammonia concentration, $<20 \mathrm{ppm}$; air exchange, 8-12 times/h; $15 \mathrm{~g}$ food added every $24 \mathrm{~h}$; drinking water, $\mathrm{pH}$ 2.5-2.8 acidified water, changed 2-3 times/week. Animal health and behavior were monitored every $12 \mathrm{~h}$. The rats were intraperitoneally anesthetized with $50 \mathrm{mg} / \mathrm{kg}$ sodium pentobarbital after weighing. After disinfection, the abdominal cavity was opened, saline was fully perfused into the apex cordis of the heart; once the kidneys turned pale, they were quickly moved onto ice. Rats were euthanized with an intraperitoneal injection of $150 \mathrm{mg} / \mathrm{kg}$ sodium pentobarbital following surgery. Subsequently, the renal capsule was discarded from the kidneys and the renal cortex along the boundary of the medulla was obtained to generate a homogenate. The tissue was then consecutively filtered through 60-, 100- and 200-mesh screens, after which, the tissue was collected and the separated glomeruli were obtained. Subsequently, $0.1 \%$ collagenase IV (cat. no. 17104019; Thermo Fisher Scientific, Inc.) was added for $10 \mathrm{~min}$ at $37^{\circ} \mathrm{C}$. The glomeruli $\left(2 \times 10^{4}\right)$ were transferred to a culture flask with DMEM (cat. no. 31600-091; Thermo Fisher Scientific, Inc.) containing 20\% fetal bovine serum (FBS; cat. no. M6546; Macklin, Inc.). After the glomeruli were adherent to the culture flask wall, the cells were cultured for 4 weeks, and the cells were digested with trypsin, subcultured and purified. The third generation of cells was used in experiments.

Cells were cultured at $37^{\circ} \mathrm{C}$ in an atmosphere containing $5 \% \mathrm{CO}_{2}$, in saturated humidity. The cells were cultured to the 8th-10th generation. When the proliferating cells reached $80-90 \%$ confluence, $0.25 \%$ trypsin was used to digest cells. A single cell suspension was prepared from DMEM containing $20 \%$ FBS). After supplementing cells with serum-free low glucose DMEM for $24 \mathrm{~h}$, the glomerular mesangial cells were randomly divided into five groups: Control (con)-short hairpin RNA (shRNA) group; con-shRNA + BAFF (20 ng/ml; cat. no. PHC1674; Thermo Fisher Scientific, Inc.) group, in which BAFF was added to transfected cells for $48 \mathrm{~h}$ at $37^{\circ} \mathrm{C}$; con-shRNA + BAFF + BAFF-receptor (R)-Fc chimera protein (500 $\mu \mathrm{g} / \mathrm{ml}$; cat. no. 1162-BR-050; R\&D Systems, Inc.) group, in which BAFF-R-Fc was added to transfected cells and after $30 \mathrm{~min}$ BAFF was added for $48 \mathrm{~h}$ at $37^{\circ} \mathrm{C}$; TRAF6-shRNA group; and TRAF6-shRNA + BAFF (20 ng/ml) group, in which BAFF was added to transfected cells for $48 \mathrm{~h}$ at $37^{\circ} \mathrm{C}$.

Transfection of glomerular mesangial cells. Glomerular mesangial cells $\left(10^{6} / \mathrm{ml}\right)$ were seeded into 24 -well plates at $500 \mu \mathrm{l}$ per well. Cells were transfected after reaching $40 \%$ confluence. A total of $100 \mu 16$ pmol TRAF6-shRNA (cat. no. sc-156004-SH; Santa Cruz Biotechnology, Inc.), $2 \mu \mathrm{l}$ Rfect (cat. no. 11011; Changzhou Baidai Biotechnology Co., Ltd.) and serum-free medium were added to each well and mixed; the cells and transfection agents were cultured at $37^{\circ} \mathrm{C}$ for $48 \mathrm{~h}$. After transfection, the cells were further cultured in RPMI-1640 medium (containing $200 \mathrm{U} / \mathrm{ml}$ penicillin $\mathrm{G}$,
$10 \mathrm{mg} / \mathrm{l}$ gentamicin and $10 \% \mathrm{FBS}$ ) overnight at $37^{\circ} \mathrm{C}$. Cells in the control group were transfected with the Con-shRNA (5'-AAGAA ACCATGCAAAGTAAGGTT-3'; Santa Cruz Biotechnology, Inc.).

Establishment of IgA nephropathy model and transfection with rats. A total of 60 Sprague-Dawley male rats (age, 8 weeks; weight, 220-260 g), supplied by the laboratory animal center of Nantong University, were randomly divided into four groups: Con-small interfering RNA (siRNA; $0.2 \mu \mathrm{M}$ ), con-siRNA $(0.2 \mu \mathrm{M})+\mathrm{IgA}$, BAFF-RFc chimera protein $(2 \mu \mathrm{g} / \mathrm{ml})+$ IgA, and TRAF6-siRNA $(0.2 \mu \mathrm{M})+\operatorname{IgA}$. Rats were housed under the following conditions: Temperature, $18-26^{\circ} \mathrm{C}$; relative humidity, 40-70\%; noise, $<85 \mathrm{~dB}$; ammonia concentration, $<20$ ppm; air exchange, 8-12 times every hour; $15 \mathrm{~g}$ food was added every $24 \mathrm{~h}$; drinking water, $\mathrm{pH}$ 2.5-2.8 acidified water, changed 2-3 times every week. Animal health and behavior were monitored every $12 \mathrm{~h}$.

TRAF6-siRNA (cat. no. sc-156004; Santa Cruz Biotechnology, Inc.) was mixed with Entranster ${ }^{\mathrm{TM}}$ in vivo (cat. no. 4000-3; Engreen Biosystem) at a ratio of 1:2. A total of $1 \mathrm{ml}$ solution was injected through the tail vein in rats, and the relevant experiments were performed after $24 \mathrm{~h}$. Rats in the control group were injected with Con-siRNA (cat. no. A06001; Shanghai GenePharma Co., Ltd.). Rats were injected with siRNAs $24 \mathrm{~h}$ prior to IgA nephropathy model generation (27).

To establish the IgA nephropathy model, Sprague-Dawley rats were acclimated for 1 week. Subsequently, the rats were anesthetized by intraperitoneal injection of $1 \%$ sodium pentobarbital $(40 \mathrm{mg} / \mathrm{kg})$ and the left kidney was removed. After 1 week, 3 mg BSA (cat. no. Abs9157; Shanghai Absin Biotechnology) mixed with complete Freund's adjuvant medium was injected into both hind footpads of the mice, followed by repeated subcutaneous multi-site injections of the same solution every 2 weeks. A total of 2 weeks after the injection of BSA into the footpads, $6 \mathrm{mmol} / 1$ hydrochloric acid-acidified water containing $0.1 \%$ BSA was administered every other day. Blood was drawn after three immunization injections of BSA, and the serum anti-BSA antibody titer was measured using the double immunodiffusion method (28). When the antibody titer reached 1:16, $3 \mathrm{mg}$ BSA was intraperitoneally injected daily. After 3 weeks, $100 \mu \mathrm{g}$ lipopolysaccharide (cat. no. L2880; Sigma-Aldrich; Merck KGaA) was intraperitoneally injected. The model was established after 4 weeks (28). After fasting for $12 \mathrm{~h}$, the rats were placed in a metabolic cage, urine was collected over $24 \mathrm{~h}$, urine volume was recorded and the 24-h urine protein quantity was measured, as aforementioned. All rats were euthanized via an intraperitoneal injection of $150 \mathrm{mg} / \mathrm{kg}$ sodium pentobarbital. Once the heartbeat stopped and pupils dilated, serum was obtained, and Scr and BAFF were detected. The methods of measurement were the same as those aforementioned for analysis of human specimens. In addition, the left kidney was removed and fixed in $10 \%$ neutralized formaldehyde solution for $2 \mathrm{~h}$ at room temperature. The samples were stored at $-80^{\circ} \mathrm{C}$ for further testing.

Nucleoplasm separation of cells and kidney tissues. Cells were treated according to the aforementioned grouping and dosing methods. Subsequently, the cells were harvested, and the nuclei were extracted using the BestBio Nucleus/Cytoplasmic 
Isolation kit (Bestbio). Subsequently, 5-10x $10^{6}$ cells were centrifuged at $500 \mathrm{x} \mathrm{g}$ for $3 \mathrm{~min}$ at $4^{\circ} \mathrm{C}$ to collect cells. Cells were washed twice with $\mathrm{PBS}$, and a mixture consisting of cold Buffer A and protease inhibitor was added. After shaking twice, the solution containing cells was centrifuged at $16,000 \mathrm{x} \mathrm{g}$ for $5 \mathrm{~min}$ at $4^{\circ} \mathrm{C}$. The mixture of cold Buffer $\mathrm{B}$ and protease inhibitor was then added to the pellet. After shaking, the cell suspension was centrifuged at $16,000 \mathrm{x} \mathrm{g}$ for $10 \mathrm{~min}$ at $4^{\circ} \mathrm{C}$, and the supernatant was quickly transferred into a precooled, clean centrifuge tube to obtain nuclear proteins.

Rat kidney samples were cut into small pieces. After adding PBS, the tissues were homogenized using a tissue homogenizer, until bulky solids were not visible after settling on ice for $5 \mathrm{~min}$. The supernatant was carefully transferred into a precooled clean centrifuge tube, followed by centrifugation at $500 \mathrm{x}$ g for $2-3 \mathrm{~min}$ at $4^{\circ} \mathrm{C}$. The supernatant was then discarded and the same procedure as aforementioned was performed to extract nuclear proteins.

Western blotting and flow cytometry for the detection of $B A F F-R$ expression in mesangial cells. The cells were collected and lyzed on ice for $30 \mathrm{~min}$ with RIPA lysis buffer (cat. no. P0013B; Beyotime Institute of Biotechnology). Centrifugation was then conducted at $8,000 \mathrm{x}$ g for $5 \mathrm{~min}$ at $4{ }^{\circ} \mathrm{C}$. Total proteins were extracted from cells and the protein concentration was determined using the bicinchoninic acid (BCA) assay. After the proteins were mixed with loading buffer for $5 \mathrm{~min}, 30 \mu \mathrm{g}$ protein was separated by SDS-PAGE on $8 \%$ gels. Proteins were then transferred to a nitrocellulose membrane and blocked with $50 \mathrm{~g} / 1 \mathrm{skim}$ milk powder in TBS- $0.05 \%$ Tween (TBST). Membranes were then incubated with anti-BAFF-R antibody $(1: 1,000$; cat. no. ab5965; Abcam) overnight at $4^{\circ} \mathrm{C}$. The corresponding HRP-labeled goat anti-rabbit secondary antibody $(1: 4,000$; cat. no. ab205718; Abcam) was added to the membrane at $4^{\circ} \mathrm{C}$ for $2 \mathrm{~h}$. Proteins were detected using an enhanced chemiluminescence (ECL) system (cat. no. PE0010; Beijing Solarbio Science \& Technology Co., Ltd.). An Odyssey ${ }^{\circledR}$ CLx Imaging system (LI-COR Biosciences) was used to capture images and densitometric analysis was conducted using Image Lab 3.0 software (Bio-Rad Laboratories, Inc.). $\beta$-actin (1:5,000; cat. no. ab95437; Abcam) was used to incubate membranes at $4^{\circ} \mathrm{C}$ overnight and was employed as a loading control.

For flow cytometric detection of BAFF-R, glomerular mesangial cells $\left(10^{7} / \mathrm{ml}\right)$ were seeded into 24 -well plates at $500 \mu \mathrm{l} /$ well. Cells were incubated with primary mouse anti-BAFF-R antibody (1:1,000; cat. no. ab233775; Abcam) for 30 min in PBS supplemented with $3 \% \mathrm{FBS}$ at $4^{\circ} \mathrm{C}$. Subsequently, cells were incubated with FITC-conjugated anti-mouse secondary antibody (1:5,000; cat. no. ab6785; Abcam) for $30 \mathrm{~min}$ at $4^{\circ} \mathrm{C}$. Rat Ig (cat. no. AS10-923; Agrisera) at the same concentration was used as a negative control. BAFF-R expression on the mesangial cell membrane was detected using an Attune NxT Flow Cytometer (Thermo Fisher Scientific, Inc.). Attune $^{\mathrm{TM}}$ NxT software version 2.1 (Thermo Fisher Scientific, Inc.) was used to analyze the results.

Reverse transcription-quantitative PCR (RT-qPCR) analysis of TRAF6, fibronectin (FN), connective tissue growth factor (CTGF) and NF-КBP65 mRNA expression in glomerular mesangial cells. After cells were treated with the aforementioned reagents, they were harvested. RNA extraction was performed using TRIzol ${ }^{\circledR}$ reagent (Invitrogen; Thermo Fisher Scientific, Inc.). A total of $1 \mathrm{ml} \mathrm{TRIzol}{ }^{\circledR}$ was added to every $1 \times 10^{6}$ cells. The integrity of the extracted product was evaluated by $1 \%$ TBE-agarose electrophoresis, and the concentration was measured using a spectrophotometer. cDNA was synthesized using a RT kit (RevertAid First Strand cDNA synthesis kit; cat. no. K1621; Thermo Fisher Scientific, Inc.). The reactions were carried in a $12-\mu 1$ volume: $3 \mu \mathrm{g}$ RNA template, $11 \mu \mathrm{l}$ primer and RNase-free ddH2O. The reaction was maintained at $70^{\circ} \mathrm{C}$ for $5 \mathrm{~min}$ and was placed in an ice bath for $30 \mathrm{sec}$. After centrifugation $(8,000 \mathrm{x} \mathrm{g}$ for $3 \mathrm{~min}$ at room temperature), the following reagents were added: $4 \mu 15 \mathrm{X}$ Reaction Buffer, $1 \mu \mathrm{l}$ RNase Inhibitor (20 U/ $\mu \mathrm{l}), 2 \mu \mathrm{ldNTP}$ Mix $(10 \mathrm{mmol} / \mathrm{l})$, and the sample was incubated at $37^{\circ} \mathrm{C}$ for $5 \mathrm{~min}$. Subsequently, $1 \mu \mathrm{l}$ M-MLV RT (20 U/ $\mu \mathrm{l})$ was added, and the sample was incubated at $37^{\circ} \mathrm{C}$ for $60 \mathrm{~min}$ and $70^{\circ} \mathrm{C}$ for $10 \mathrm{~min}$. SYBR Green II qPCR reagent (SYBR premix Ex Taq II; cat. no. DRR820A; Takara Bio, Inc.) was used for qPCR with an ABI 7300 cycler (Applied Biosystems; Thermo Fisher Scientific, Inc.). For consistent amplification efficiency, each specimen was tested for TRAF6, CTGF, FN, NF-кBP65 and GAPDH gene expression. The total reaction system comprised $20 \mu \mathrm{l}$, which included $10 \mu \mathrm{l}$ 2X Real Master Mix, $0.4 \mu \mathrm{l}$ ROX, $0.8 \mu \mathrm{l}$ each of the upstream and downstream primers, and $2 \mu \mathrm{g}$ cDNA as a reaction template. The thermocycling conditions were as follows: Initial denaturation at $95^{\circ} \mathrm{C}$ for $3 \mathrm{~min}$, followed by 40 cycles of denaturation at $95^{\circ} \mathrm{C}$ for $15 \mathrm{sec}$, primer annealing at $62^{\circ} \mathrm{C}$ for $30 \mathrm{sec}$ and elongation at $72^{\circ} \mathrm{C}$ for $30 \mathrm{sec}$, and a final elongation step at $72^{\circ} \mathrm{C}$ for $7 \mathrm{~min}$. The fluorescence signal was recorded after reading the plate to obtain a melting curve; the melting curve was then analyzed. Samples were randomly selected for $2 \%$ agarose gel electrophoresis to determine whether the amplified products were the desired fragments. Quantum CX5 (Vilber Lourmat) was used to capture images and densitometric analysis was conducted using AlphaImager 2000 image analyzer (Alpha Innotech). With GAPDH as the housekeeping gene, $2^{-\Delta \Delta \mathrm{Cq}} \times 100 \%$ indicated the relative expression of each gene: $\Delta \mathrm{Cq}($ test $)=\mathrm{Cq}$ (target,test)$\mathrm{Cq}$ (ref,test); $\Delta \mathrm{Cq}$ (calibrator) $=\mathrm{Cq}$ (target, calibrator) $\mathrm{Cq}$ (ref,cal ibrator); $\Delta \Delta \mathrm{Cq}=\Delta \mathrm{Cq}$ (test) $-\Delta \mathrm{Cq}$ (calibrator). Calibrator refers to the control group; test refers to the experimental group(s); ref refers to the housekeeping gene; target refers to the gene of interest. Three replicate wells were set for each reaction to calculate the mean value for each $\Delta \mathrm{Cq}$ (29). Primers were designed by Shanghai Bioengineering, as follows: TRAF6, forward (F) 5'-TGATAGTGTGGGTGGAACTGC-3', reverse (R) 5'-CAGATGGGGCATTCATACTTG-3'; FN, F 5'-CCG GTGGCTGTCAGTCAAAG-3', R 5'-AAACCTCGGCTT CCTCCATAA-3'; CTGF, F 5'-CCCTGACCCAACTATGAT GC-3', R 5'-CCTTACTCCCTGGCTTTACG-3'; NF-кBP65, F 5'-TTCCTGGCGAGAGAAGCAC-3', R 5'-AAGCTATGG ATACTGCCCTCT-3'; and GAPDH, F 5'-ACGGATTTGCTC GTATTG-3' and R 5'-GGAAGATGGTGATGGGATT-3'

Western blot analysis of the protein expression levels of TRAF6, FN, CTGF and p-NF-кBP65 in glomerular mesangial cells. Glomerular mesangial cells were treated according to cell groups for $48 \mathrm{~h}$, after which, total protein 
was extracted by lysing cells on ice with $150 \mu 1$ RIPA lysis solution in each well of a 6 -well plate. The protein concentration was determined using a BCA protein quantitative kit (Beyotime Institute of Biotechnology). Total and nuclear proteins $(60 \mu \mathrm{g} / \mathrm{well})$ were separated by SDS-PAGE on $8 \%$ gels and were transferred to a nitrocellulose membrane. The membranes were blocked with TBST containing 5\% skim milk powder at room temperature for $1 \mathrm{~h}$, and were then incubated with anti-TRAF6 (1:1,000; cat. no. ab33915; Abcam), anti-FN (1:1,000; cat. no. MA517075; Thermo Fisher Scientific, Inc.), anti-CTGF (1:1,000; cat. no. ab6992; Abcam), anti-p-NF-кBP65 (1:1,000; cat. no. ab86299; Abcam), anti-NF-кBP65 (1:1,000; cat.no.ab16502; Abcam), anti- $\beta$-actin (1:5,000; cat. no. ab95437; Abcam) and anti-Histone H3 (1:5,000; cat. no. ab176842; Abcam) overnight at $4^{\circ} \mathrm{C}$. After sufficient washing with TBST (5 min/three times), HRP-conjugated secondary antibodies (1:5,000; cat. no. ab205718; Abcam; and cat. no. 31430; Thermo Fisher Scientific, Inc.) was added at room temperature for $1 \mathrm{~h}$. Proteins were detected using an ECL system. An Odyssey ${ }^{\circledR}$ CLx Imaging system (LI-COR Biosciences) was used to capture images and densitometric analysis was conducted using Image Lab 3.0 software (Bio-Rad Laboratories, Inc.). $\beta$-actin was used as a cytoplasmic loading control; Histone $\mathrm{H} 3$ was used as nuclear-specific loading control.

Western blotting to detect protein expression levels of BAFF, TRAF6, FN, CTGF and p-NF-кBP65 in rat kidney tissues. A total of $200 \mu \mathrm{l}$ RIPA lysis solution (Beyotime Institute of Biotechnology) was added per $20 \mathrm{mg}$ kidney tissue samples to extract proteins. The extracted total and nuclear protein samples $(60 \mu \mathrm{g} /$ well $)$ were subjected to SDS-PAGE on $8 \%$ gels. After electrophoresis, the samples were transferred to polyvinylidene difluoride membranes, which were blocked with TBST containing $5 \%$ skim milk powder at $4^{\circ} \mathrm{C}$ overnight. Membranes were then washed twice with TBST, and incubated with anti-BAFF $(1: 1,000$; cat. no. ab8396; Abcam), anti-FN $(1: 1,000)$, anti-TRAF6 (1:1,000), anti-CTGF $(1: 1,000)$ anti- $\beta$-actin $(1: 5,000)$, anti-Histone H3 $(1: 5,000)$,

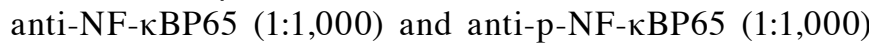
at $37^{\circ} \mathrm{C}$ for $2 \mathrm{~h}$, and were washed twice with TBST for $10 \mathrm{~min}$. The membranes were then incubated with the aforementioned secondary antibodies $(1: 2,000)$ at $37^{\circ} \mathrm{C}$ for $2 \mathrm{~h}$, and washed with TBST four times (10 $\mathrm{min} /$ wash). The chemiluminescence method (GE Healthcare) was used for visualization. The Odyssey imaging system was used to develop images. ImageJ software (National Institutes of Health) was used for densitometric analysis; grayscale values of target proteins were normalized to the loading proteins. $\beta$-actin was used as a cytoplasmic loading control; Histone H3 was used as nuclear-specific loading control.

Statistical analysis. Statistical analysis was performed using SPSS statistical software for Windows, version 17.0 (SPSS, Inc.). The experiments were conducted three times. Data are expressed as the mean \pm standard deviation. Data were analyzed by one-way ANOVA followed by a Tukey post hoc test for multiple groups, and by Student's t-test for two groups. The correlation between two variables was analyzed using Pearson's correlation. $\mathrm{P}<0.05$ was considered to indicate a statistically significant difference.

\section{Results}

Plasma BAFF levels in patients with IgA nephropathy are positively correlated with the Katafuchi score of renal damage. With the aggravation of pathological damage, the proteinuria level of patients with IgA nephropathy increased. In addition, plasma BAFF levels were significantly increased and the endogenous creatinine clearance rate was decreased. Pairwise comparisons were made between the groups, and these differences were statistically significant $(\mathrm{P}<0.05$; Fig. 1). Proteinuria $(r=0.45 ; \mathrm{P}<0.05)$ and BAFF levels $(\mathrm{r}=0.62$; $\mathrm{P}<0.05)$ were positively correlated with the Katafuchi score of renal damage (data not shown). The endogenous creatinine clearance rate was negatively correlated with the Katafuchi score of renal damage $(\mathrm{r}=-0.72 ; \mathrm{P}<0.05)$ (data not shown). The expression levels of BAFF, TRAF6, FN, p-NF- $\kappa$ Bp65 and CTGF were markedly higher in the kidneys of patients with IgA nephropathy than those in the control group. The overexpression of proteins was mainly concentrated in the glomerular mesangial area (Fig. 2).

$B A F F-R$ is expressed on the surface of glomerular mesangial cells. Western blotting was used to detect the expression of BAFF-R protein. The results revealed that there was a small amount of BAFF-R protein expression in mesangial cells. Following the addition of $20 \mathrm{ng} / \mathrm{ml}$ BAFF for $48 \mathrm{~h}$, the protein expression levels of BAFF-R were significantly increased in mesangial cells $(\mathrm{P}<0.05)$.The presence of BAFF-R on the surface of the mesangial cell membrane was confirmed by flow cytometry (Fig. 3).

$B A F F$ induces the mRNA expression levels of TRAF6,

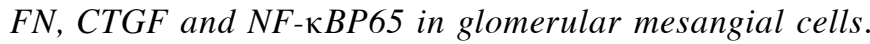
Following the addition of $20 \mathrm{ng} / \mathrm{ml}$ BAFF to glomerular mesangial cells for $48 \mathrm{~h}$, the mRNA expression levels of FN, TRAF6, CTGF and NF- $\mathrm{BP} 65$ were significantly increased in the glomerular mesangial cells $(\mathrm{P}<0.05$ vs. the control group). Glomerular mesangial cells transfected with the shRNA-TRAF6 plasmid exhibited reduced expression of TRAF6 mRNA ( $\mathrm{P}<0.05$ vs. the control group), and following treatment with $20 \mathrm{ng} / \mathrm{ml}$ BAFF for $48 \mathrm{~h}$, the mRNA expression levels of NF- $\mathrm{NBP} 65$ were significantly lower than those observed in the con-shRNA + BAFF group, and the mRNA expression levevls of FN and CTGF were also decreased $(\mathrm{P}<0.05$ vs. the con-shRNA + BAFF group; Fig. 4).

BAFF enhances expression of TRAF6, FN, CTGF and nuclear $p-N F-\kappa B P 65$ proteins in glomerular mesangial cells. Following the addition of $20 \mathrm{ng} / \mathrm{ml}$ BAFF to the glomerular mesangial cells for $48 \mathrm{~h}$, the protein expression levels of TRAF6 in mesangial cells and p-NF- $\mathrm{kP} 65$ in the nuclei of mesangial cells were significantly increased. Notably, total $\mathrm{NF}-\kappa \mathrm{B}$ protein expression in the cells did not change, and the proportion of $\mathrm{p}-\mathrm{F}-\kappa \mathrm{BP} 65 / \mathrm{NF}-\kappa \mathrm{BP} 65$ was significantly higher $(\mathrm{P}<0.05 \mathrm{vs}$. the control group). In addition, the expression levels of the downstream proteins, FN and CTGF, were enhanced by BAFF treatment ( $\mathrm{P}<0.05$ vs. the control group). Mesangial cells transfected with the shRNA-TRAF6 plasmid exhibited reduced expression of TRAF6 protein $(\mathrm{P}<0.05$ vs. the control group), and after $48 \mathrm{~h}$ of treatment with $20 \mathrm{ng} / \mathrm{ml}$ 

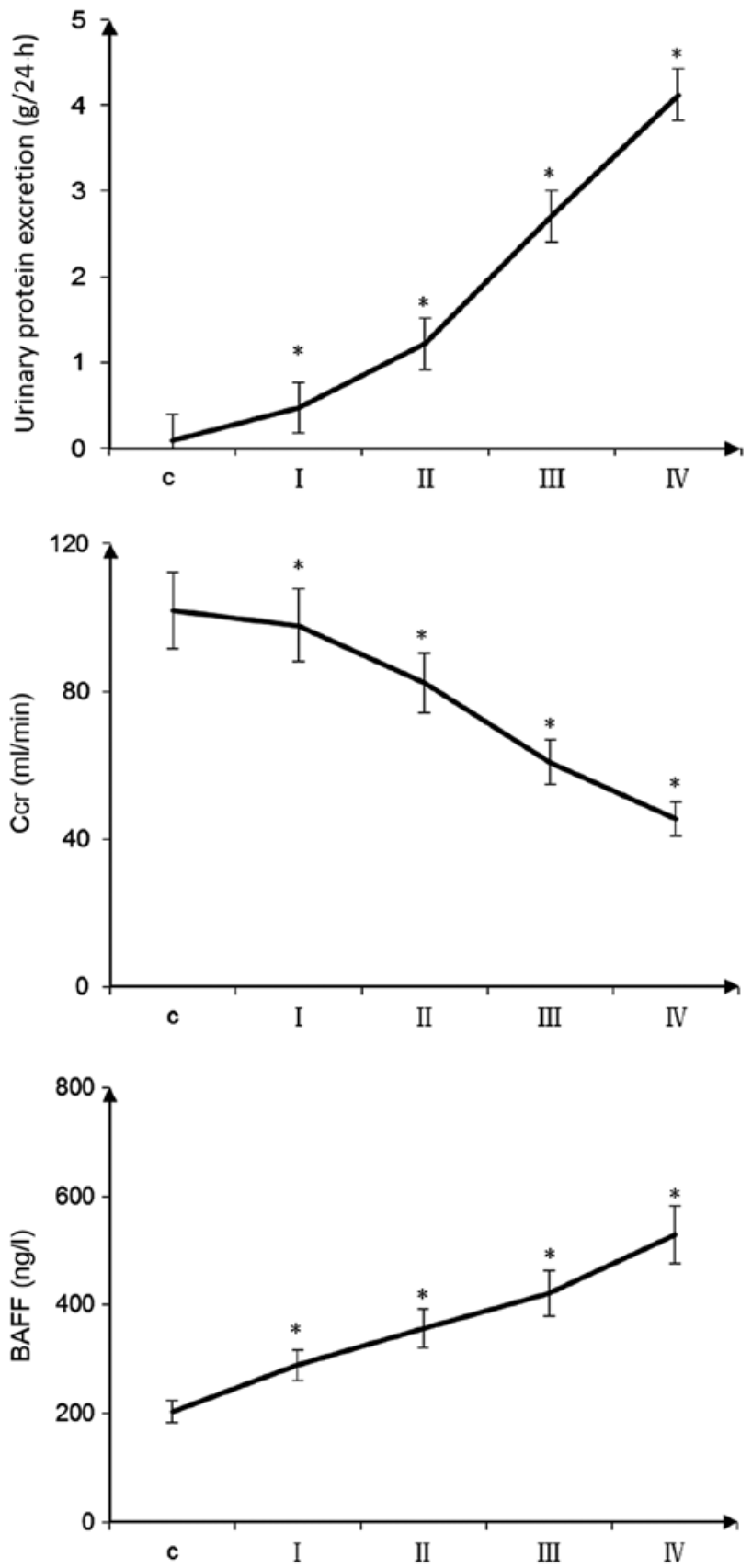

Figure 1. Clinical indicators of patients with IgA nephropathy. The 24-h urine protein content and plasma BAFF concentrations of patients with IgA nephropathy were increased with increasing glomerular pathological score. Endogenous Ccr decreased with increasing glomerular pathological score ( $\mathrm{P}<0.05$, pairwise comparisons between groups: I vs. C, II vs. I, III vs. II, IV vs. III). Scoring groups: I, 0-3 points; II, 4-6 points; III, 7-9 points; and IV, 10-12 points. BAFF, B cell-activating factor; C, control; Ccr, creatinine clearance rate.

BAFF, the protein expression levels of p-NF- $\mathrm{kBP} 65$ in the nucleus were significantly lower than those observed in the con-shRNA + BAFF group, and FN and CTGF protein expression was also decreased $(\mathrm{P}<0.05$ vs. con-shRNA + BAFF group; Fig. 5).

TRAF6-siRNA inhibits the expression of TRAF6 in rat kidney tissues. When TRAF6-siRNA was administered into the tail vein of rats, the protein expression levels of TRAF6 in the kidneys of rats with IgA nephropathy were significantly decreased $(\mathrm{P}<0.05)$. These findings suggested that TRAF6 expression in the kidneys of rats with IgA nephropathy was successfully inhibited by TRAF6-siRNA (Fig. 6).

Plasma BAFF, proteinuria and serum creatinine levels are significantly increased in rats with IgA nephropathy. Proteinuria, serum creatinine concentration and plasma BAFF concentration of rats in the $\operatorname{IgA}$ nephropathy group were significantly higher than those in the control group $(\mathrm{P}<0.05)$. In the Fc + IgA and TRAF6-siRNA groups, plasma BAFF concentration was not significantly different compared with the IgA nephropathy group $(\mathrm{P}>0.05)$; however, the other two markers were significantly lower than those in the $\operatorname{Ig} \mathrm{A}$ nephropathy group $(\mathrm{P}<0.05$; Fig. 7).

$B A F F$ may enhance the expression of fibroblast factors in the kidneys by activating the TRAF6/NF- $\kappa B$ signaling pathway. The expression levels of BAFF, TRAF6, p-NF- $\mathrm{BP} 65$, FN and CTGF in the kidneys of rats with IgA nephropathy were markedly increased compared with in the control group $(\mathrm{P}<0.05)$, and these proteins were mainly distributed in the glomerular mesangial area. The expression levels of BAFF in the TRAF6-siRNA + IgA and Fc groups were not significantly different from those in the IgA nephropathy group $(\mathrm{P}>0.05)$; however, the expression levels of TRAF6, p-NF-KBP65, FN and CTGF were significantly lower than those observed in the IgA nephropathy group ( $\mathrm{P}<0.05$; Fig. 8).

Inhibition of BAFF- $R$ binding and the TRAF6/NF- $\kappa B$ signaling pathway may reduce kidney damage in rats with IgA nephropathy. The expression levels of BAFF, TRAF6, FN, CTGF and nuclear p-NF-кBP65 proteins in rats with IgA nephropathy were significantly higher than those in the control group $(\mathrm{P}<0.05)$. Notably, total NF- $\kappa \mathrm{B}$ protein expression in the cells did not change, whereas the proportion of p-NF- $\kappa$ BP65/NF- $\kappa$ BP65 was significantly higher $(\mathrm{P}<0.05$ vs. the control group). In the TRAF6-siRNA + $\mathrm{IgA}$ and $\mathrm{Fc}$ groups, the protein expression levels of BAFF were not significantly different from those in the $\operatorname{Ig} A$ nephropathy group $(\mathrm{P}>0.05)$; however, the expression levels of TRAF6, FN, CTGF and nuclear p-NF-кBP65 proteins were significantly lower than those in the $\operatorname{IgA}$ nephropathy group $(\mathrm{P}<0.05$; Fig. 9).

\section{Discussion}

The pathogenesis of $\operatorname{Ig} \mathrm{A}$ nephropathy is complex and is a key area of research. The pathogenesis of $\operatorname{IgA}$ nephropathy involves the activation of $\mathrm{B}$ cells and the production of abnormal glycosylated IgA1 (30). BAFF is an important activator for B-cell activation, which induces B-cell proliferation, differentiation and the secretion of immunoglobulin; it also serves an important role in humoral immunity (31). Previous studies have reported that synthetic double-stranded RNA poly (I) aggravates kidney damage in rats with $\operatorname{IgA}$ nephropathy through the Toll-like receptor 3-BAFF signaling pathway (32-35). The present study demonstrated that plasma BAFF levels in patients with IgA nephropathy were significantly higher than those in the 


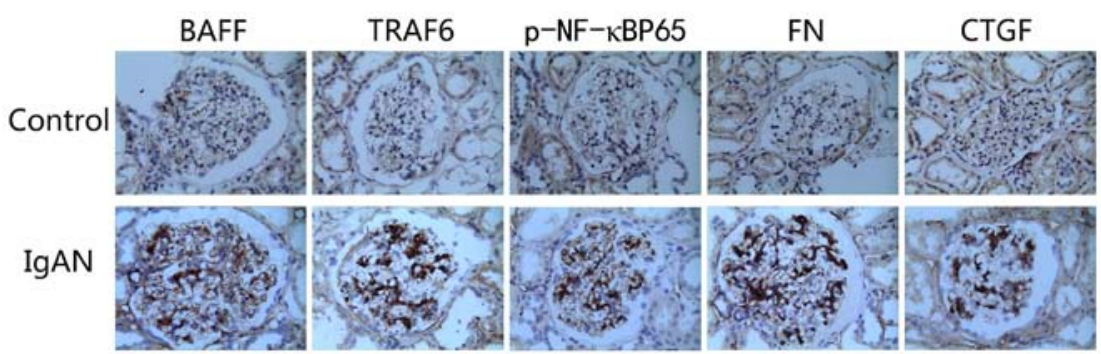

Figure 2. Immunohistochemistry to detect the expression of various factors in the kidneys of patients with IgAN (magnification, $x 400$ ). In comparison with the healthy control group, the expression levels of BAFF, TRAF6, p-NF-kBp65, FN and CTGF were markedly increased in the kidneys of patients with IgAN. BAFF, B cell-activating factor; CTGF, connective tissue growth factor; FN, fibronectin; IgAN, IgA nephropathy; p-, phosphorylated; TRAF, tumor necrosis factor receptor-associated factor.
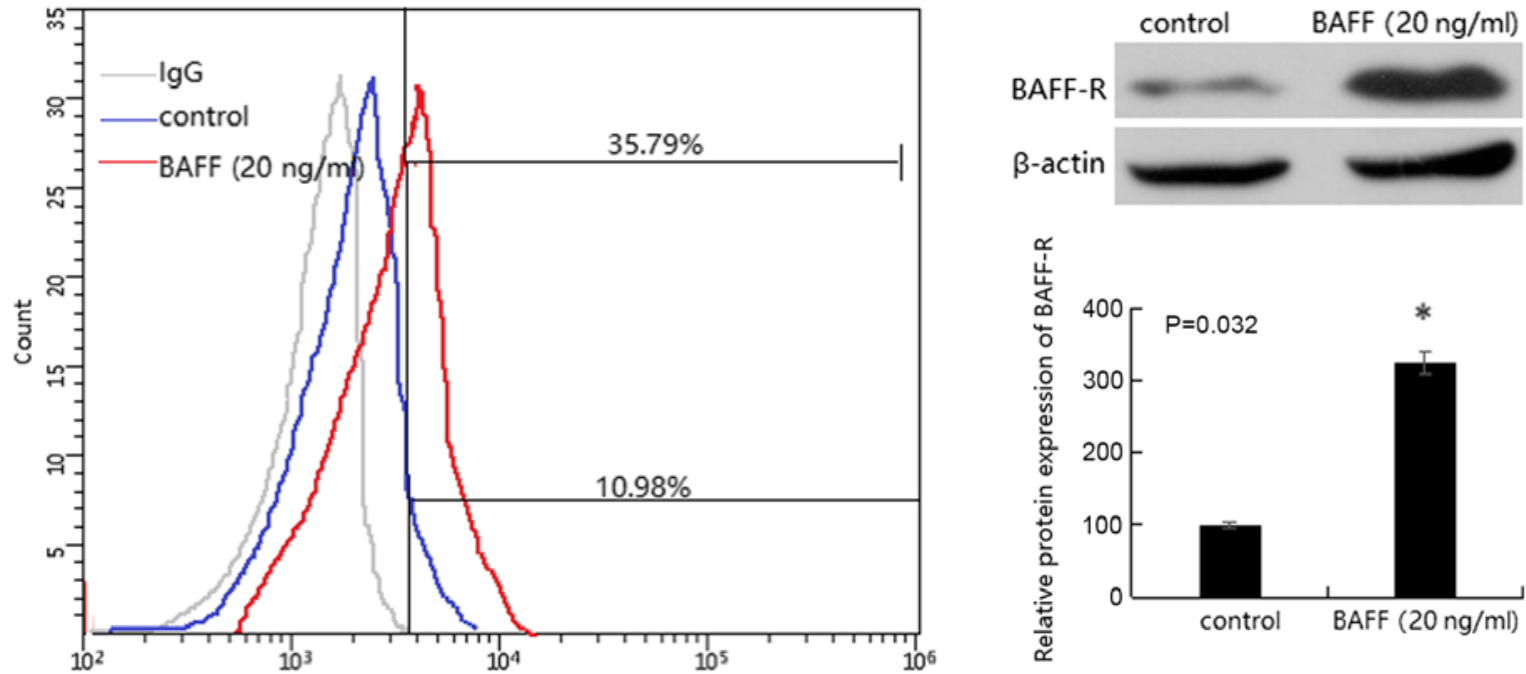

Figure 3. Expression of BAFF-R in mesangial cells. The presence of BAFF-R on the surface of human mesangial cells was detected using the BAFF-R antibody by flow cytometry. Rat Ig at the same concentration was used as a negative control. Western blotting was performed to detect BAFF-R expression in mesangial cells and was significantly increased when stimulated with BAFF $(\mathrm{P}=0.032)$. $\mathrm{P}<0.05$. BAFF, B cell-activating factor; BAFF-R, BAFF receptor.

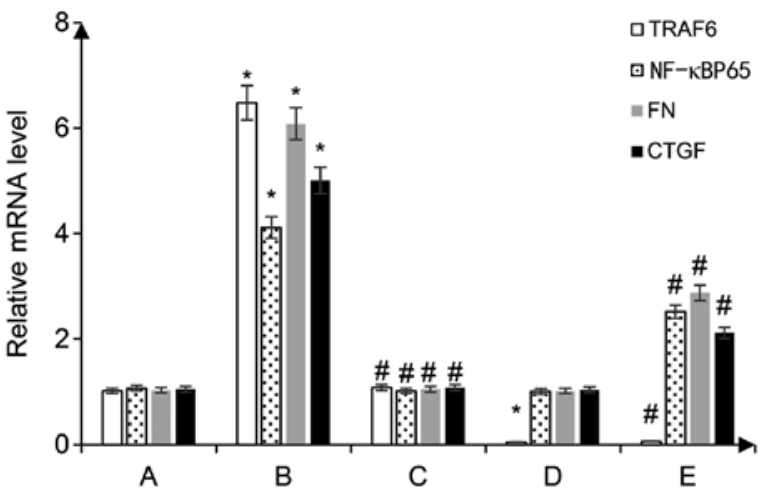

Figure 4. Reverse transcription-quantitative PCR was performed to detect the mRNA expression levels of NF-kBp65 and TRAF6, FN and CTGF in the cytoplasm. A, con-shRNA; B, con-shRNA + BAFF; C, con-shRNA + BAFF + BAFF-RFc chimera protein; D, TRAF6-shRNA; E, TRAF6-shRNA + BAFF. ${ }^{*} \mathrm{P}<0.05$ vs. group $\mathrm{A}$; ${ }^{\#} \mathrm{P}<0.05$ vs. group B. BAFF $\mathrm{B}$ cell-activating factor; BAFF-R, BAFF receptor; CTGF, connective tissue growth factor; FN, fibronectin; p-, phosphorylated; TRAF, tumor necrosis factor receptor-associated factor; shRNA, short hairpin RNA; con-, control.

control group, and were positively correlated with Katafuchi scores, which was consistent with the results reported by Xin et al (13). These results suggested that BAFF levels were closely associated with the severity of $\operatorname{Ig}$ A nephropathy. In addition, the results revealed that BAFF expression in the kidneys of patients with IgA nephropathy was significantly increased and was positively correlated with protein concentrations in the urine; they were also negatively correlated with the clearance rate of endogenous creatinine. These results suggested that BAFF may serve a key role in the pathogenesis of IgA nephropathy.

It has been reported that BAFF binds to its receptor to promote the survival, proliferation, differentiation and maturation of cells by recruiting TRAF and activating JNK, Rel/NF- $\kappa$ B and MAPK (36). By using a yeast two-hybrid system, Xu and Shu (37) demonstrated that TRAF3 could bind to the intracellular domain of BAFF-R and negatively regulate BAFF-R-mediated NF- $\mathrm{KB}$ activation and IL-10 production. Members of the matrix protein family (TRAF1, -2 and -6 ), could induce inflammatory immunity and the apoptotic effect by mediating different signaling pathways. Pullen et al (38) reported that TRAF6 mediated the strongest $\mathrm{NF}-\kappa \mathrm{B}$ activation downstream of CD40 in TRAF family members, and the CD40-mediated NF- $\mathrm{KB}$ signaling pathway was inactivated in TRAF6-deficient splenocytes. The activation of NF- $\kappa B$ and downstream inflammatory factors is highly associated with the occurrence of IgA nephropathy. 


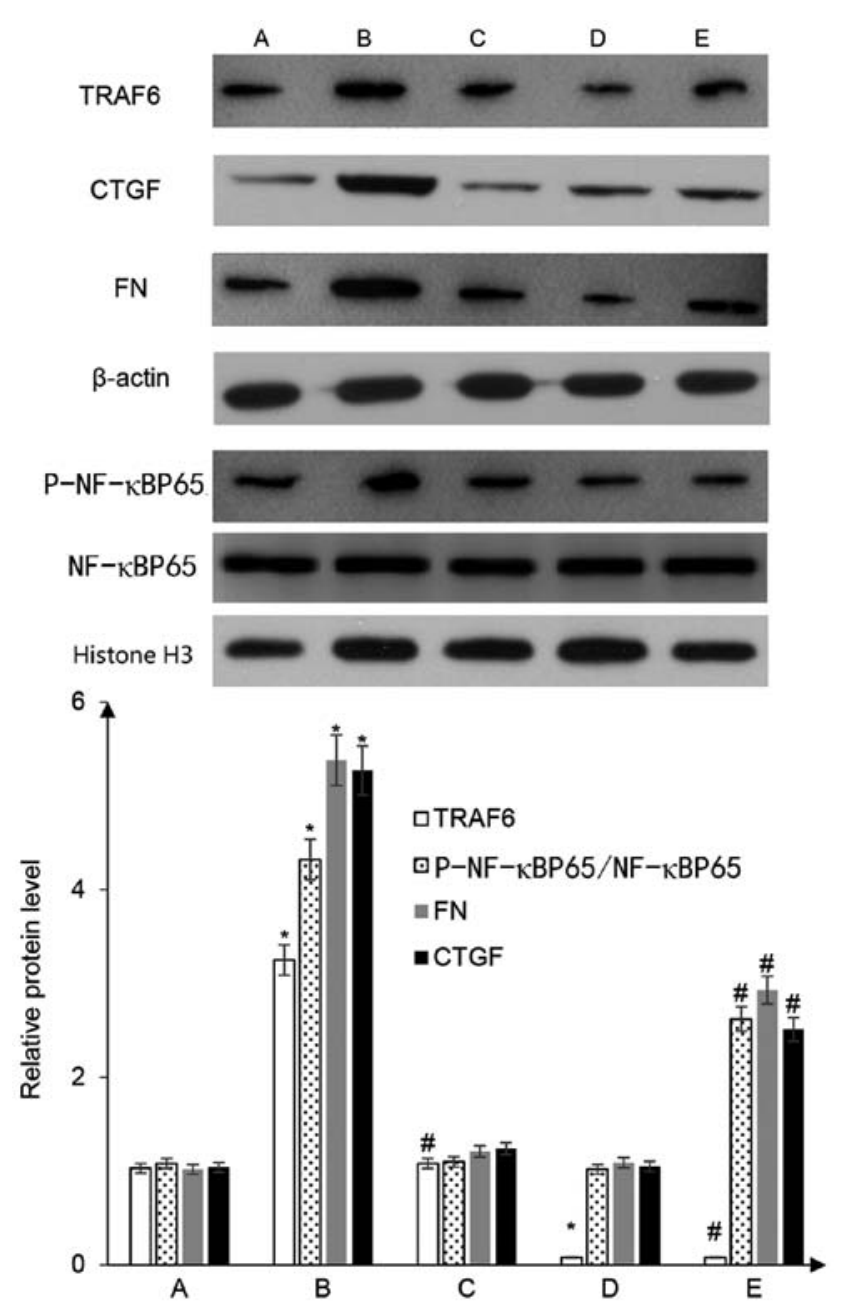

Figure 5. Western blot analysis to detect the protein expression levels of TRAF6, p-NF- $\mathrm{BP} 65, \mathrm{FN}$ and CTGF in glomerular mesangial cells. A, con-shRNA; B, con-shRNA + BAFF; C, con-shRNA + BAFF + BAFF-RFc chimera protein; D, TRAF6-shRNA; E, TRAF6-shRNA + BAFF. "P $<0.05$ vs. group $\mathrm{A} ;{ }^{\#} \mathrm{P}<0.05$ vs. group $\mathrm{B}$. BAFF, B cell-activating factor; BAFF-R, $\mathrm{BAFF}$ receptor; CTGF, connective tissue growth factor; FN, fibronectin; p-, phosphorylated; TRAF, tumor necrosis factor receptor-associated factor; shRNA, short hairpin RNA; con-, control.

These findings suggested that BAFF-mediated activation of $\mathrm{B}$ cells and the associated TRAF6/NF- $\mathrm{KB}$ pathway further led to the release of downstream inflammatory factors, which in turn serve a critical role in the pathogenesis of immune diseases; however, this mechanism has not been reported in IgA nephropathy.

Notably,our preliminary experiments revealed that plasma BAFF levels were significantly elevated in patients with $\operatorname{IgA}$ nephropathy compared with in controls, and the expression levels of TRAF6/NF- $\mathrm{kB}$ signaling pathway-related proteins were also markedly increased in the kidneys of patients with IgA nephropathy. These findings suggested that BAFF may be involved in the pathogenesis of IgA nephropathy through the TRAF6/NF- $\kappa \mathrm{B}$ signaling pathway. This hypothesis has been further confirmed in the present cell culture and animal model experiments. It has previously been reported that BAFF-R is expressed on the surface of mesangial cells (9). In the present in vitro cell culture study, the expression of BAFF-R on the cell surface was confirmed by flow cytometry and western blotting. Following stimulation with

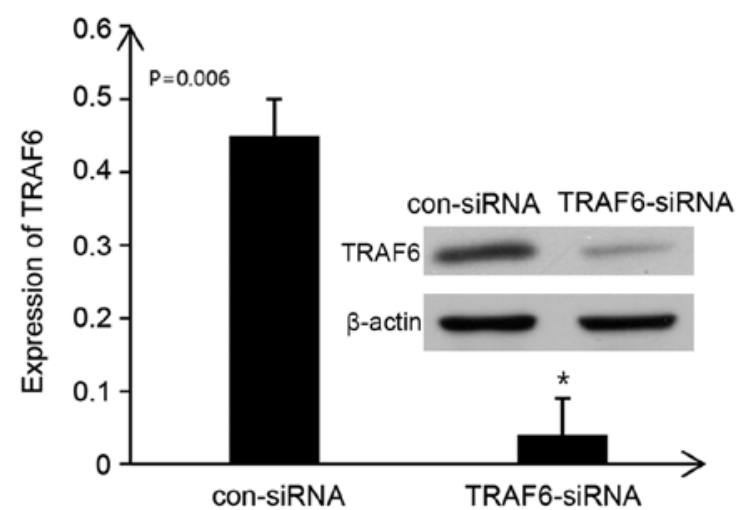

Figure 6. Western blot analysis was used to detect the protein expression levels of TRAF6 in rat kidney tissues. After TRAF6-siRNA was administered into the rat tail vein for $24 \mathrm{~h}$ the expression of TRAF6 proteins in rat kidney tissues was detected by western blot analysis, and the expression levels were significantly reduced. " $\mathrm{P}<0.05$. con-, control; siRNA, small interfering RNA; TRAF, tumor necrosis factor receptor-associated factor.
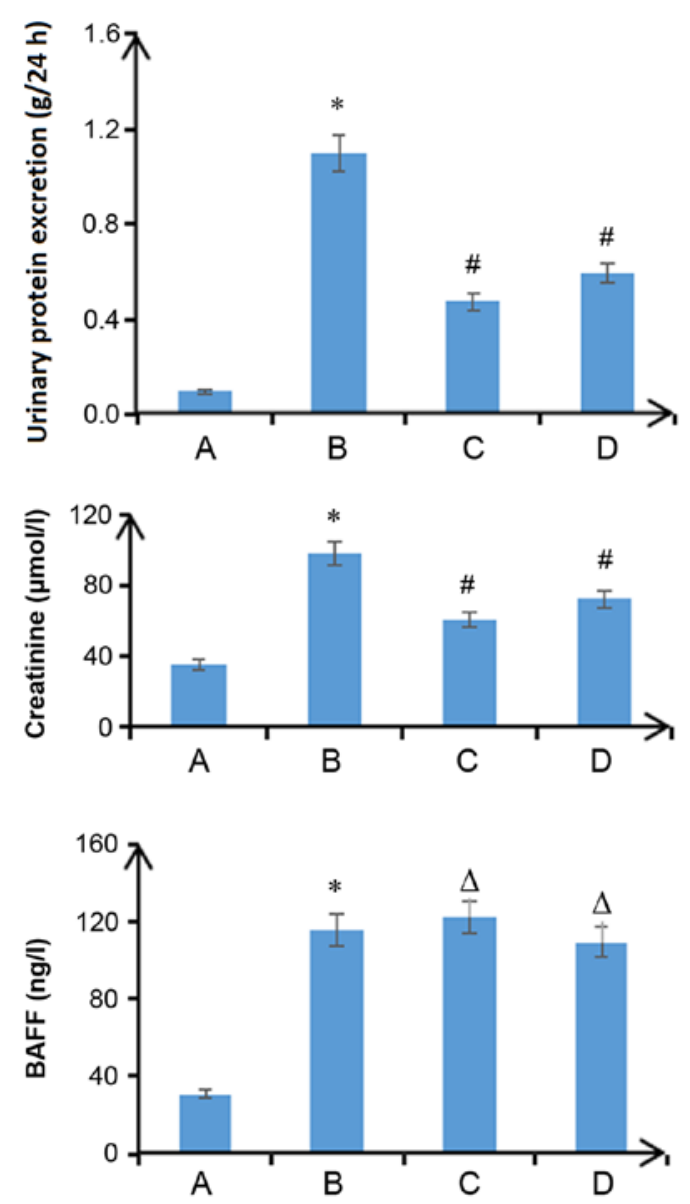

Figure 7. Clinical indicators of rats in the IgA nephropathy model group. A, con-siRNA; B, con-siRNA + IgA; C, BAFF-RFc chimera protein + IgA; $\mathrm{D}, \mathrm{TRAF} 6$-siRNA + IgA. ${ }^{*} \mathrm{P}<0.05$ vs. group $\mathrm{A} ;{ }^{\circ} \mathrm{P}>0.05$ vs. group $\mathrm{B} ;{ }^{*} \mathrm{P}<0.05$ vs. group B. BAFF, B cell-activating factor; siRNA, small interfering RNA; TRAF, tumor necrosis factor receptor-associated factor.

BAFF, BAFF-R expression was increased. In addition, the results revealed that TRAF6 expression was increased following BAFF stimulation and the nuclear expression levels of the transcription factor NF-кBP65 were increased to further activate the release of downstream cytokines FN 


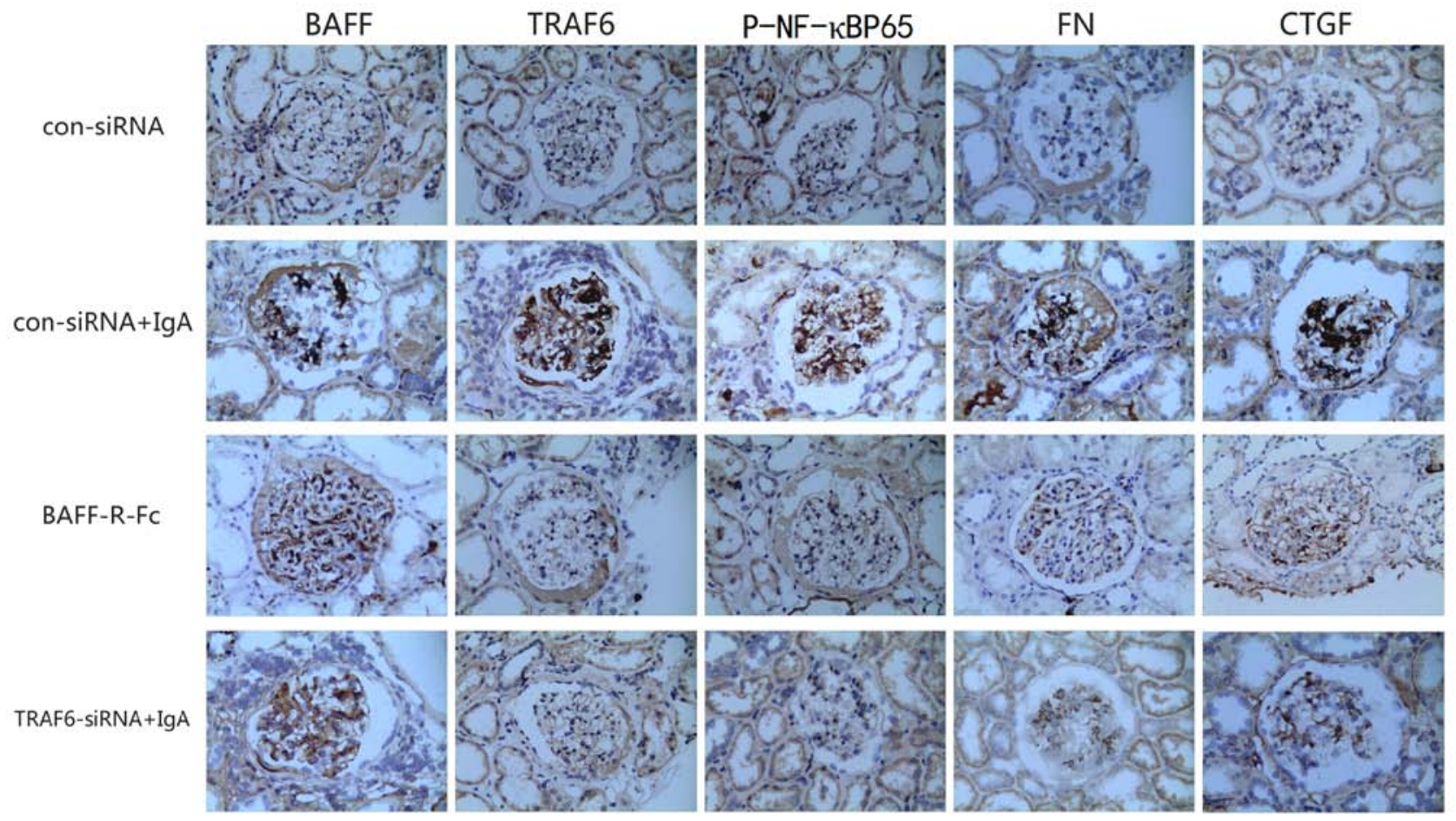

Figure 8. Immunohistochemistry to detect the expression of various factors in rat kidney tissues (magnification, $\mathrm{x} 400$ ). BAFF, B cell-activating factor; CTGF, connective tissue growth factor; FN, fibronectin; p-, phosphorylated; siRNA, small interfering RNA; TRAF, tumor necrosis factor receptor-associated factor.

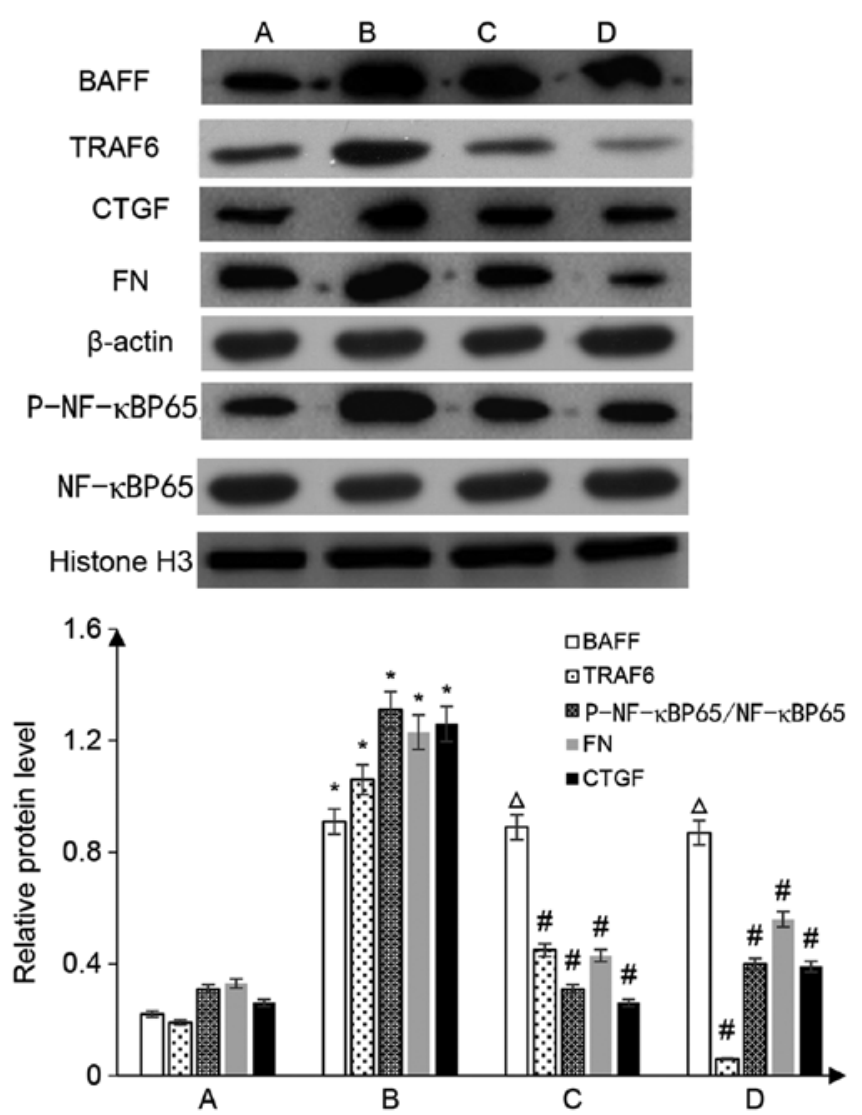

Figure 9. Western blot analysis to detect the expression levels of marker proteins in kidney tissues. A, con-siRNA; B, con-siRNA + IgA; C, BAFF-RFc chimera protein + IgA; D, TRAF6-siRNA + IgA. * $\mathrm{P}<0.05$ vs. group $\mathrm{A} ;{ }^{\mathrm{A}} \mathrm{P}>0.05$ vs. group $\mathrm{B} ;{ }^{*} \mathrm{P}<0.05$ vs. group $\mathrm{B}$. BAFF, B cell-activating factor; CTGF, connective tissue growth factor; FN, fibronectin; p-, phosphorylated; siRNA, small interfering RNA; TRAF, tumor necrosis factor receptor-associated factor. and CTGF; this may lead to proliferation and apoptosis of glomerular mesangial cells. Furthermore, these markers were significantly reduced following treatment with the BAFF-R Fc chimera protein, suggesting that BAFF could be critical in binding to BAFF-R. The expression of endogenous TRAF6 was significantly inhibited post-transfection with the shRNA-TRAF6 plasmid, and the expression levels of NF- $\mathrm{NBP} 65$ in the nucleus were reduced, resulting in a reduction in the release of the corresponding downstream cytokines. These results demonstrated that BAFF may induce the proliferation of mesangial cells and the production of fibrotic factors by activating the TRAF6/NF-KB signaling pathway via binding to BAFF-R.

In the IgA nephropathy model animals, plasma BAFF levels were significantly increased compared with in animals in the control group, and the expression levels of TRAF6 and p-NF- $\kappa$ BP65 were increased. These increased expression levels were mainly in the mesangial regions. These results were consistent with patients with IgA nephropathy. It was suggested that the high level of BAFF expression in patients with $\operatorname{Ig}$ A nephropathy may be involved in the activation of signaling pathways and development of $\operatorname{Ig} \mathrm{A}$ nephropathy. Administration of the BAFF-R Fc chimera protein, in order to interfere with the binding of BAFF and BAFF-R, had no effect on plasma BAFF levels; however, it did significantly inhibit activation of the TRAF6/NF- $\kappa \mathrm{B}$ signaling pathway. A previous study reported that siRNA injection into the rat tail vein can successfully silence related gene expression (27). In this study, administration of TRAF6-siRNA into the tail vein had no effect on plasma BAFF levels; however, TRAF6 expression was almost non-existent in rat kidneys in response to TRAF6-siRNA. TRAF-6 siRNA also resulted in reduced expression of nuclear $\mathrm{p}-\mathrm{NF}-\kappa \mathrm{BP} 65$ and reduced release of the 
corresponding cytokines. The present results revealed that in the animal model of Ig A nephropathy, the plasma levels of BAFF were increased, and the TRAF6/NF-KB signaling pathway in mesangial cells was activated by binding to BAFF-R, which may increased fibrogenic factor release, thus leading to glomerular fibrosis.

In conclusion, the results of the present study indicated that BAFF may be involved in the pathogenesis of IgA nephropathy by binding to BAFF-R and activating the TRAF6/NF- $\mathrm{KB}$ signaling pathway. These results provide a novel avenue for searching for targets for the treatment of IgA nephropathy. However, BAFF has three receptors; whether the other two receptors could be involved in the process will be the focus of future studies.

\section{Acknowledgements}

Not applicable.

\section{Funding}

This study was supported by the Projects of Science and Technology Funds of Nantong (grant no. MSZ18086).

\section{Availability of data and materials}

The datasets used and/or analyzed during the present study are available from the corresponding author on reasonable request.

\section{Authors' contributions}

YC and GL conceived and coordinated the study, and designed, performed and analyzed the experiments. YC wrote the manuscript. XiC, XuC and NG carried out data collection and data analysis, and revised the paper. WL carried out animal experiments. All authors reviewed the results and approved the final version of the manuscript.

\section{Ethics approval and consent to participate}

The study protocol was approved by the medical ethics committee of the Affiliated Hospital of Nantong University, and all subjects provide written informed consent. The animal protocol in the present study was approved by the Medical Ethics Committee of The Nantong University Affiliated Hospital.

\section{Patient consent for publication}

Not applicable.

\section{Competing interests}

The authors declare that they have no competing interests.

\section{References}

1. Lee K, Shin J, Park J, Hwang S, Jang HR, Huh W, Kwon GY, Kim YG, Oh HY, Lee JE and Kim DJ: First-year GFR slope and long-term renal outcome in IgA nephropathy. Eur J Clin Invest 48: e12936, 2018.
2. Roberts IS: Pathology of IgA nephropathy. Nat Rev Nephrol 10: 445-454, 2014.

3. Coppo R: Treatment of IgA nephropathy: Recent advances and prospects. Nephrol Ther 14 (Suppl 1): S13-S21, 2018.

4. Rauen T and Floege J: Inflammation in IgA nephropathy. Pediatr Nephrol 32: 2215-2224, 2017.

5. Coppo R: Biomarkers and targeted new therapies for $\operatorname{Ig} A$ nephropathy. Pediatr Nephrol 32: 725-731, 2017.

6. Xie YX, He LY, Chen X, Peng XF, Ye MY, Zhao YJ, Yan WZ, Liu C, Shao J and Peng YM: Potential diagnostic biomarkers for IgA nephropathy: A comparative study pre- and post-tonsillectomy. Int Urol Nephrol 48: 1855-1861, 2016.

7. Li C, Shi J and Zhao Y: MiR-320 promotes B cell proliferation and the production of aberrant glycosylated $\operatorname{IgA} 1$ in $\operatorname{Ig} \mathrm{A}$ nephropathy. J Cell Biochem 119: 4607-4614, 2018.

8. Park SJ, Oh JY and Shin JI: Could increased IgA induced by BAFF be the cause of IgA nephropathy development in Behcet's disease? Comment on: Behcet's disease and IgA nephropathy (Rheumatol Int. 2012 Jul; 32(7):2227-9). Rheumatol Int 34: 283-284, 2014.

9. Zheng $\mathrm{N}$, Wang D, Ming $\mathrm{H}$, Zhang $\mathrm{H}$ and Yu X: BAFF promotes proliferation of human mesangial cells through interaction with BAFF-R. BMC Nephrol 16: 72, 2015.

10. Ye M, Peng Y, Liu C, Yan W, Peng X, He L, Liu H and Liu F: Vibration induces BAFF overexpression and aberrant O-Glycosylation of IgA1 in cultured human tonsillar mononuclear cells in IgA nephropathy. Biomed Res Int 2016: 9125960, 2016.

11. Zheng N, Fan J, Wang B, Wang D, Feng P, Yang Q and Yu X: Expression profile of BAFF in peripheral blood from patients of $\operatorname{IgA}$ nephropathy: Correlation with clinical features and Streptococcus pyogenes infection. Mol Med Rep 15: 1925-1935, 2017.

12. Shao J, Peng Y, He L, Liu H, Chen X and Peng X: Capsaicin induces high expression of BAFF and aberrantly glycosylated IgA1 of tonsillar mononuclear cells in IgA nephropathy patients. Hum Immunol 75: 1034-1039, 2014.

13. Xin G, Shi W, Xu LX, Su Y, Yan LJ and Li KS: Serum BAFF is elevated in patients with IgA nephropathy and associated with clinical and histopathological features. J Nephrol 26: 683-690, 2013.

14. McCarthy DD, Kujawa J, Wilson C, Papandile A, Poreci U, Porfilio EA, Ward L, Lawson MA, Macpherson AJ, McCoy KD, et al: Mice overexpressing BAFF develop a commensal flora-dependent, IgA-associated nephropathy. J Clin Invest 121: 3991-4002, 2011

15. Walsh MC, Lee J and Choi Y: Tumor necrosis factor receptor-associated factor 6 (TRAF6) regulation of development, function, and homeostasis of the immune system. Immunol Rev 266: 72-92, 2015.

16. Kanaya T, Sakakibara S, Jinnohara T, Hachisuka M, Tachibana N, Hidano S, Kobayashi T, Kimura S, Iwanaga T, Nakagawa T, et al: Development of intestinal $\mathrm{M}$ cells and follicle-associated epithelium is regulated by TRAF6-mediated NF-KB signaling. J Exp Med 215: 501-519, 2018

17. Fang J, Muto T, Kleppe M, Bolanos LC, Hueneman KM, Walker CS, Sampson L, Wellendorf AM, Chetal K, Choi K, et al: TRAF6 mediates basal activation of NF-KB necessary for hematopoietic stem cell homeostasis. Cell Rep 22: 1250-1262, 2018.

18. Zhou Y, Jin XH, Jing YX, Song Y, He XX, Zheng LL, Wang YB, Wei ZY and Zhang GP: Porcine parvovirus infection activates inflammatory cytokine production through Toll-like receptor 9 and NF-KB signaling pathways in porcine kidney cells. Vet Microbiol 207: 56-62, 2017

19. Cai M, Li M, Wang K, Wang S, Lu Q, Yan J, Mossman KL, Lin R and Zheng $C$ : The herpes simplex virus 1-encoded envelope glycoprotein B activates NF-KB through the Toll-like receptor 2 and MyD88/TRAF6-dependent signaling pathway. PLoS One 8: e54586, 2013.

20. He X, Zheng Y, Liu S, Shi S, Liu Y, He Y, Zhang C and Zhou X: MiR-146a protects small intestine against ischemia/reperfusion injury by down-regulating TLR4/TRAF6/NF-KB pathway. J Cell Physiol 233: 2476-2488, 2018.

21. Wang P, Cao J, Liu S, Pan H, Liu X, Sui A, Wang L, Yao R, Liu Z and Liang J: Upregulated microRNA-429 inhibits the migration of HCC cells by targeting TRAF6 through the NF-KB pathway. Oncol Rep 37: 2883-2890, 2017.

22. Liu J, Zhang Z, Guo Q, Dong Y, Zhao Q and Ma X: Syringin prevents bone loss in ovariectomized mice via TRAF6 mediated inhibition of NF-KB and stimulation of PI3K/AKT. Phytomedicine 42: 43-50, 2018. 
23. Zhong JH, Li J, Liu CF, Liu N, Bian RX, Zhao SM, Yan SY and Zhang YB: Effects of microRNA-146a on the proliferation and apoptosis of human osteoarthritis chondrocytes by targeting TRAF6 through the NF-KB signalling pathway. Biosci Rep 37: BSR20160578, 2017.

24. Guobing X, Lili J, Lihua Z and Tiean X: Application of an improved biuret method to the determination of total protein in urine and cerebrospinal fluid without concentration step by use of Hitachi 7170 auto-analyzer. J Clin Lab Anal 15: 161-164, 2001.

25. Shoker A, Hossain MA, Koru-Sengul T, Raju DL and Cockcroft D: Performance of creatinine clearance equations on the original Cockcroft-Gault population. Clin Nephrol 66: 89-97, 2006.

26. Katafuchi R, Kiyoshi Y, Oh Y, Uesugi N, Ikeda K, Yanase T and Fujimi S: Glomerular score as a prognosticator in IgA nephropathy: Its usefulness and limitation. Clin Nephrol 49: 1-8, 1998.

27. Lei Y, Tang L, Xie Y, Xianyu Y, Zhang L, Wang P, Hamada Y, Jiang K, Zheng W and Jiang X: Gold nanoclusters-assisted delivery of NGF siRNA for effective treatment of pancreatic cancer. Nat Commun 8: 15130, 2017.

28. Yang L, Wang Y, Nuerbiye A, Cheng P, Wang JH, Kasimu R and $\mathrm{Li} \mathrm{H}$ : Effects of periostracum cicadae on cytokines and apoptosis regulatory proteins in an IgA nephropathy rat model. Int J Mol Sci 19: E1599, 2018

29. Livak KJ and Schmittgen TD: Analysis of relative gene expression data using real-time quantitative PCR and the 2(-Delta Delta $\mathrm{C}(\mathrm{T})$ ) method. Methods 25: 402-408, 2001.

30. He L, Peng X, Wang J, Tang C, Zhou X, Liu H, Liu F, Sun L and Peng Y: Synthetic Double-stranded RNA Poly(I:C) aggravates $\operatorname{Ig} \mathrm{A}$ nephropathy by triggering IgA class switching recombination through the TLR3-BAFF Axis. Am J Nephrol 42: 185-197, 2015.

31. Mackay F, Figgett WA, Saulep D, Lepage M and Hibbs ML: B-cell stage and context-dependent requirements for survival signals from BAFF and the B-cell receptor. Immunol Rev 237 205-225, 2010.
32. Li W, Peng X, Liu Y, Liu H, Liu F, He L, Liu Y, Zhang F, Guo C, Chen G, et al: TLR9 and BAFF: Their expression in patients with IgA nephropathy. Mol Med Rep 10: 1469-1474, 2014.

33. Tang $X$, Zhang $L$ and Wei W: Roles of TRAFs in NF-KB signaling pathways mediated by BAFF. Immunol Lett 196: 113-118, 2018.

34. Tian J, Jiao X, Wang X, Geng J, Wang R, Liu N, Gao X, Griffin N and Shan F: Novel effect of methionine enkephalin against influenza $A$ virus infection through inhibiting TLR7-MyD88-TRAF6-NF-KB p65 signaling pathway. Int Immunopharmacol 55: 38-48, 2018.

35. Hildebrand JM, Luo Z, Manske MK, Price-Troska T, Ziesmer SC, Lin W, Hostager BS, Slager SL, Witzig TE, Ansell SM, et al: A BAFF-R mutation associated with non-Hodgkin lymphoma alters TRAF recruitment and reveals new insights into BAFF-R signaling. J Exp Med 207: 2569-2579, 2010.

36. Chen JX, Shen HH, Niu M, Guo YM, Liu XQ, Han YZ, Zhang YM, Zhao YL, Bai BK, Zhou WJ and Xiao XH: Anti-hepatitis B virus effect of matrine-type alkaloid and involvement of p38 mitogen-activated protein kinase and tumor necrosis factor receptor-associated factor 6. Virus Res 215: 104-113, 2016.

37. Xu LG and Shu HB: TNFR-associated factor-3 is associated with BAFF-R and negatively regulates BAFF-R-mediated NF-kappa B activation and IL-10 production. J Immunol 169: 6883-6889, 2002.

38. Pullen SS, Dang TT, Crute JJ and Kehry MR: CD40 signaling through tumor necrosis factor receptor-associated factors (TRAFs). Binding site specificity and activation of downstream pathways by distinct TRAFs. J Biol Chem 274: 14246-14254, 1999.

This work is licensed under a Creative Commons Attribution-NonCommercial-NoDerivatives 4.0 International (CC BY-NC-ND 4.0) License. 